\title{
STUDIES ON COMPARATIVE IMPACT OF CHITOSAN AND PENICILLIUM EXPANSUM FOR FLAVONOIDS ELICITATION IN BLUMEA LACERA (BURM. F.) DC CELL CULTURE
}

\author{
Patade Priyanka, Mendhulkar Vijay D*, Vakil Moinuddin \\ Department of Botany, The Institute of Science, 15, Madam Cama Road, Mumbai- 400032.
}

*Corresponding Author Email: profmendhulkar@gmail.com

\begin{abstract}
Elicitation of flavonoids in cell suspension culture of Blumea lacera (Burm.f.) DC was carried out using chemical elicitor, chitosan and biological elicitor, Penicillium expansum. Each elicitor was used in three different concentration and treatment duration. Chitosan was used in $5 \mathrm{mg}, 10 \mathrm{mg}, 20 \mathrm{mg}$ concentration Whereas $0.3 \%, 0.6 \%$ and $1.2 \%$ of Penicillium expansum homogenate was used as elicitor. Aluminium chloride colorimetric assay revealed that Chitosan with higher dose $(20 \mathrm{mg})$ was the most favourable treatment dose among all the studied treatment concentrations and durations that yields maximum elicitation of flavonoids (3.5 fold, $96 \mathrm{hr}$ treatment). The treatment of Penicillium expansum elicitor revealed most fluctuating results for flavonoid at lower and moderate treatment duration (2 and 5 days). The total flavonoid content $(0.057 \mathrm{mg} / \mathrm{g}$ ) was measured in $0.3 \%$ of Penicillium expansum elicitor with 5 days treatment duration. The treatment of higher dose of Penicillium expansum elicitor and treatment duration had no impact on flavonoid elicitation.
\end{abstract}

\section{KEY WORDS}

Blumea lacera, Chitosan, Elicitation, Flavonoids, Penicillium expansum

\section{INTRODUCTION}

Plants are recognized as important resource of secondary metabolites which provide industrially important natural products like colour, insecticides, antimicrobials, fragrances, therapeutics etc. Plant derived secondary metabolites have played an essential role as medicine for thousands of years. It has been estimated that $80 \%$ of the population cannot afford the products of the Western Pharmaceutical Industry and must rely on the medicinal product derived from the plant material ${ }^{1}$. So, there is a great demand of plant based medicines. In recent years, Plant tissue cultures technique have been an alternate option to traditional plant extraction for obtaining valuable phytochemicals throughout the year ${ }^{2,3}$. The enhancement in production of biologically active compounds by in-vitro techniques has been achieved most successfully and promisingly in many medicinal plants ${ }^{4}$. Large-scale production of secondary metabolites has been achieved in many plant systems. Moreover, efficient in vitro production of secondary metabolites needs high effective systems with optimized cultivation conditions, use of elicitors ${ }^{5-}$ ${ }^{8}$, or simulation of nutritional deficiency of cells ${ }^{9}$, use of permeabilizing agents ${ }^{10,11}$.

Elicitors are the compounds which, when introduced in small concentrations to a living cell system, initiates or improves the biosynthesis of specific compounds ${ }^{12}$. Elicitors are signal triggering elements that contribute enhanced synthesis of secondary metabolites. They are classified based on their nature and origin into abiotic or biotic elicitors 13,14 . The biological elicitors (components of microbial cells and poly- and oligosaccharides), chemical elicitors (heavy metals, pesticides, and the signaling compounds in plant defense responses), or physical factors (cold shock, UV, 
hyperosmotic stress, ultrasound, and pulsed electric field) induce enzymatic activity against stress which result in enhanced production of secondary metabolites 15-17.

Blumea lacera (Burm.f.) DC (family- Asterceae), is an erect annual herb with strong odour of turpentine. In Ayurveda, Blumea lacera is described as thermogenic, anti-inflammatory, ophthalmic, digestive, anthelmintic, liver tonic, expectorant, good for bronchitis, antipyretic, stimulant and memory enhancer ${ }^{18}$. The plant is astringent, diuretic, and useful in catarrhal affections ${ }^{19}$. In Homeopathy, Blumea lacera is used for pitta and kapha, abdominal disorders, bronchitis, intermittent fever, and cholera ${ }^{20}$.

In the present study, the effect of chemical elicitor, Chitosan, and biological elicitor, Penicillium expansum on flavonoid biosynthesis in the cell suspension culture of Blumea lacera was investigated. The parameters such as type of elicitor, elicitor concentration and treatment duration on flavonoid production were studied in detail. To the best of our knowledge, this is the first report on elicitation of flavonoid in $B$. lacera cell suspension using Chitosan and Penicillium expansum as chemical and biological elicitor respectively.

\section{MATERIALS AND METHODS}

Plant material and establishment of callus culture: Young leaves of Blumea lacera were used as explants source for initiation of callus. Callus and cell suspension culture were established according to our previous report ${ }^{21}$.

Preparation of elicitor: The cell suspension was treated with Chitosan (chemical elicitor) and Penicillium expansum (biological elicitor).

The stock solution of Chitosan was prepared by dissolving $100 \mathrm{mg}$ Chitosan in $5 \%(\mathrm{v} / \mathrm{v}) 1 \mathrm{~N} \mathrm{HCl}$ with gentle heating and continuous stirring. After complete dissolution, the $\mathrm{pH}$ of the solution was adjusted to 5 with $1 \mathrm{~N} \mathrm{NaOH}$ and the final concentration was adjusted to $100 \mathrm{mg} / 10 \mathrm{ml}$. The stock solution was autoclaved at $15 \mathrm{lbs}$ for $20 \mathrm{~min}$. before use. $5 \mathrm{mg}, 10 \mathrm{mg}$ and $20 \mathrm{mg}$ of Chitosan was added to $50 \mathrm{ml}$ cell suspension culture of B. lacera at late exponential phase (21 days) for 24,48 and $96 \mathrm{hr}$ treatment duration. These cultures were incubated at $25 \pm 2{ }^{\circ} \mathrm{C}$ in gyratory shaker (120 rpm) under dark condition.

Penicillium expansum used for elicitation were obtained from Institute of Microbial technology, Chandigarh. The fungal cultures were maintained separately as slants in culture tubes containing Czapek dox agar. After two weeks, both the fungi were grown separately in $250 \mathrm{ml}$ flasks containing $100 \mathrm{ml}$ of Czapek dox broth under dark and static condition at room temperature for three weeks. The flask containing fungal cultures along with Czapek dox agar broth was autoclaved at 15 psi for 20 min. The mycelial mat was separated and washed several times with demineralized water. The mycelial residue was resuspended in an amount of demineralized water equal to that of the filtrate and homogenized. This homogenate was autoclaved again and used without further purification.0.3\%, $0.6 \%$ and $1.2 \%$ of this fungal homogenate was administered in cell suspension culture of $B$. lacera at late exponential phase for the treatment duration of 2 days, 5 days, and 8 days. The control was maintained with each set of treatment. $0.3 \%, 0.6 \%$ and $1.2 \%$ of the homogenate were equivalent to $4.08 \mathrm{mg}, 8.16 \mathrm{mg}$, and $16.32 \mathrm{mg}$ of fungal polysaccharide $\mathrm{I}^{-1}$ respectively. The total carbohydrate content of the fungal homogenate was determined by the phenol sulfuric acid assay using glucose as the standard.

Sample preparation for flavonoid quantification: After each elicitor treatment, cell suspensions were filtered and the cells were washed several times with distilled water. The filtered cells were dried in oven at $40^{\circ} \mathrm{C}$. Completely oven dried samples of all treatments were powdered using mortar and pestle. $100 \mathrm{mg}$ of powdered sample was sonicated in $2 \mathrm{ml}$ methanol using $2 \mathrm{~mm}$ probe for $10 \mathrm{~min}$ with pulse rate operating at 10 secs on and 2 sec off, amplitude $20 \%$ using SONICS Vibra Cell (VCX 130) instrument. After sonication, the extract was centrifuged at $5000 \mathrm{rpm}$ for $5 \mathrm{~min}$. The supernatant was transferred into $2 \mathrm{ml}$ eppendorf tubes. This extract was used for identification and quantification of flavonoids by HPTLC and UV-Vis spectrophotometer respectively.

Identification and quantification of total flavonoid content:

Identification of flavonoids was done by using High Performance Thin Layer Chromatography (HPTLC) and quantification of total flavonoid content was done with UV- Vis Spectrophotometer by Aluminium Chloride Colorimetric method.

High Performance Thin layer chromatography (HPTLC): HPTLC analysis was performed on aluminium-backed precoated silica gel 60 F254 TLC plate $(0.2 \mathrm{~mm}$ 
thickness, E. Merck). $10 \mu \mathrm{l}$ of sample solution were applied as $8 \mathrm{~mm}$ wide bands, $8 \mathrm{~mm}$ apart, by the sprayon technique, by means of a Camag (Switzerland) Linomat IV sample applicator fitted with a 100- $\mu$ I syringe (Hamilton, Bonaduz make, Switzerland). Plates were developed with mobile phase Ethyl acetate: formic acid: acetic acid: water (13.42:1.47:1.47:3.62). Plates were heated for 10 minutes. Visualization of the flavonoids was achieved by spraying the plates with ethanolic Polyethylene glycol (4000 MW) and estimated under UV light with a wavelength of $365 \mathrm{~nm}^{22}$.

\section{Estimation of Total Flavonoid Content:}

Total flavonoids content was determined using the aluminum chloride colorimetric method ${ }^{23}$. Quercetin procured from Sigma-Aldrich was used as reference standard.

\section{RESULTS AND DISCUSSION}

In the present experimental work, the impact of chemical elicitors, Chitosan, and biological elicitor, was studied on the total flavonoid content.

\section{Elicitation by Chemical elicitor, Chitosan:}

The doses and treatment durations for Chitosan were justified on reviewing work reported by earlier workers. Cell suspension cultures were treated with $5 \mathrm{mg}, 10 \mathrm{mg}$ and $20 \mathrm{mg}$ Chitosan for 24, 48 and $96 \mathrm{hr}$ treatment durations.
Identification of flavonoids in Chitosan treated cell suspension samples was done by High Performance Thin Layer Chromatography (HPTLC). Yellow coloured bands of flavonoids were visible on TLC plate after derivatization (Fig.1). The total flavonoid content in sample was measured by Aluminium Chloride assay Chitosan concentrations $5 \mathrm{mg}, 10 \mathrm{mg}$ and $20 \mathrm{mg}$ for 24 $\mathrm{hr}$ treatment duration showed $0.034 \pm 0.011,0.017 \pm$ 0.006 and $0.052 \pm 0.008 \mathrm{mg} / \mathrm{g}$ total flavonoid content respectively. The content was more as compared to control $(0.021 \pm 0.007 \mathrm{mg} / \mathrm{g})$ in $5 \mathrm{mg}$ and $20 \mathrm{mg}$ concentrations of Chitosan whereas $10 \mathrm{mg}$ Chitosan showed less flavonoid quantity than control. Highest flavonoid content was observed in 20 mg concentration of Chitosan. In case of $48 \mathrm{hr}$ treatment duration, total flavonoid content was noticed as $0.067 \pm 0.021 \mathrm{mg} / \mathrm{g}$ in 5 $\mathrm{mg}, 0.089 \pm 0.011 \mathrm{mg} / \mathrm{g}$ in $10 \mathrm{mg}$ and $0.108 \pm 0.018 \mathrm{mg} / \mathrm{g}$ for $20 \mathrm{mg}$ concentration in context to $0.044 \pm 0.009 \mathrm{mg} / \mathrm{g}$ in control. All the three studied concentrations showed gradual enhancement in total flavonoid content. Highest content was observed in $20 \mathrm{mg}$ of Chitosan treatment. For $96 \mathrm{hr}$ duration, $5 \mathrm{mg}$ Chitosan showed $0.017 \pm 0.011 \mathrm{mg} / \mathrm{g}, 10 \mathrm{mg}$ Chitosan indicated $0.056 \pm$

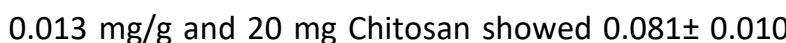
$\mathrm{mg} / \mathrm{g}$ flavonoid content against $0.023 \pm 0.009 \mathrm{mg} / \mathrm{g}$ in control.

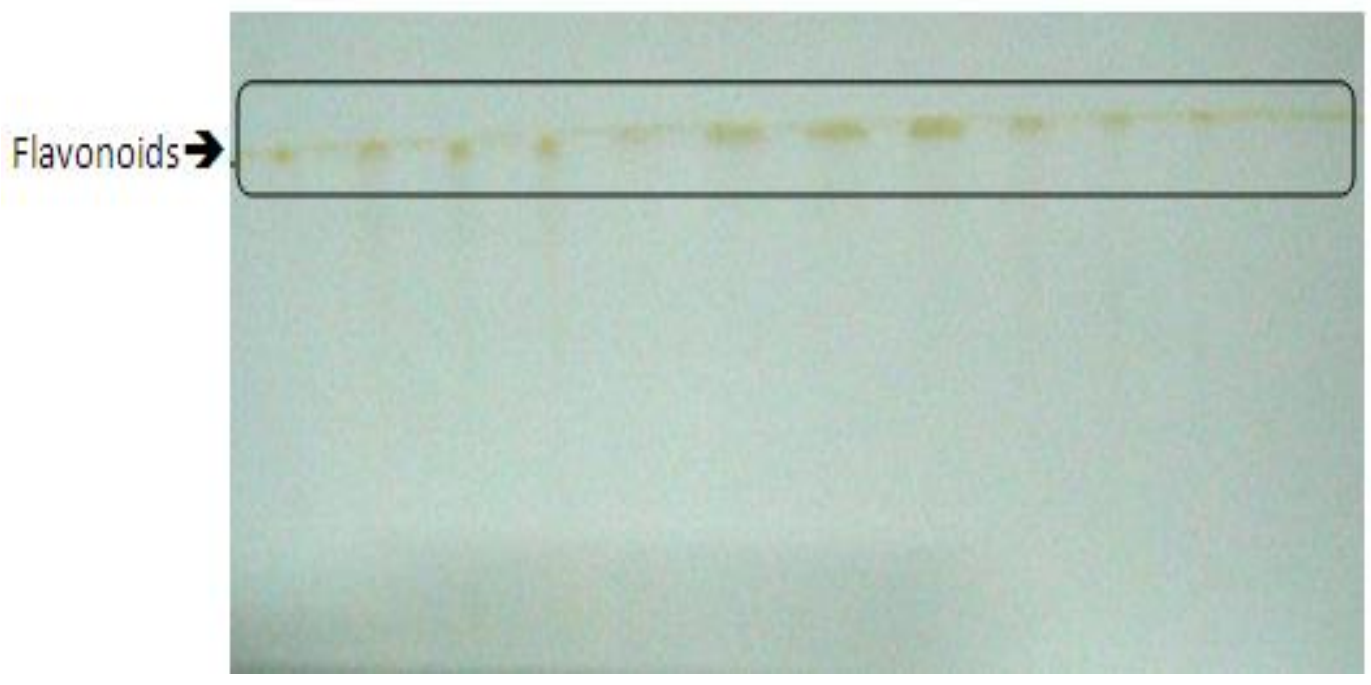

Fig. 1: HPTLC chromatogram showing flavonoids as yellow band

The estimate of flavonoid was more in 10 and $20 \mathrm{mg}$ concentration of Chitosan but it was less in $5 \mathrm{mg}$ concentration compared to control. Highest content was recorded in $20 \mathrm{mg}$ concentration of Chitosan for 96 hr duration. 
Out of studied treatment durations, $24 \mathrm{hr}$ treatment duration showed 2.5-fold increase over the control. In case of $48 \mathrm{hr}$ and $96 \mathrm{hr}$ treatment duration 2.5 -fold and 3.5-fold increase was observed respectively. Maximum fold increase was observed for $96 \mathrm{hr}$ treatment duration. It was noticed that for all the studied treatment durations, highest concentration of Chitosan i.e. $20 \mathrm{mg}$ was favourable for the enhancement of total flavonoid content. In Chitosan, mediated elicitation treatment, the most favourable concentration and treatment duration was $20 \mathrm{mg}$ for $96 \mathrm{hr}$ (Table -1; Fig. 2).

Table 1: Total content in Blumea lacera cell suspension cultures treated with Chemical elicitor, Chitosan

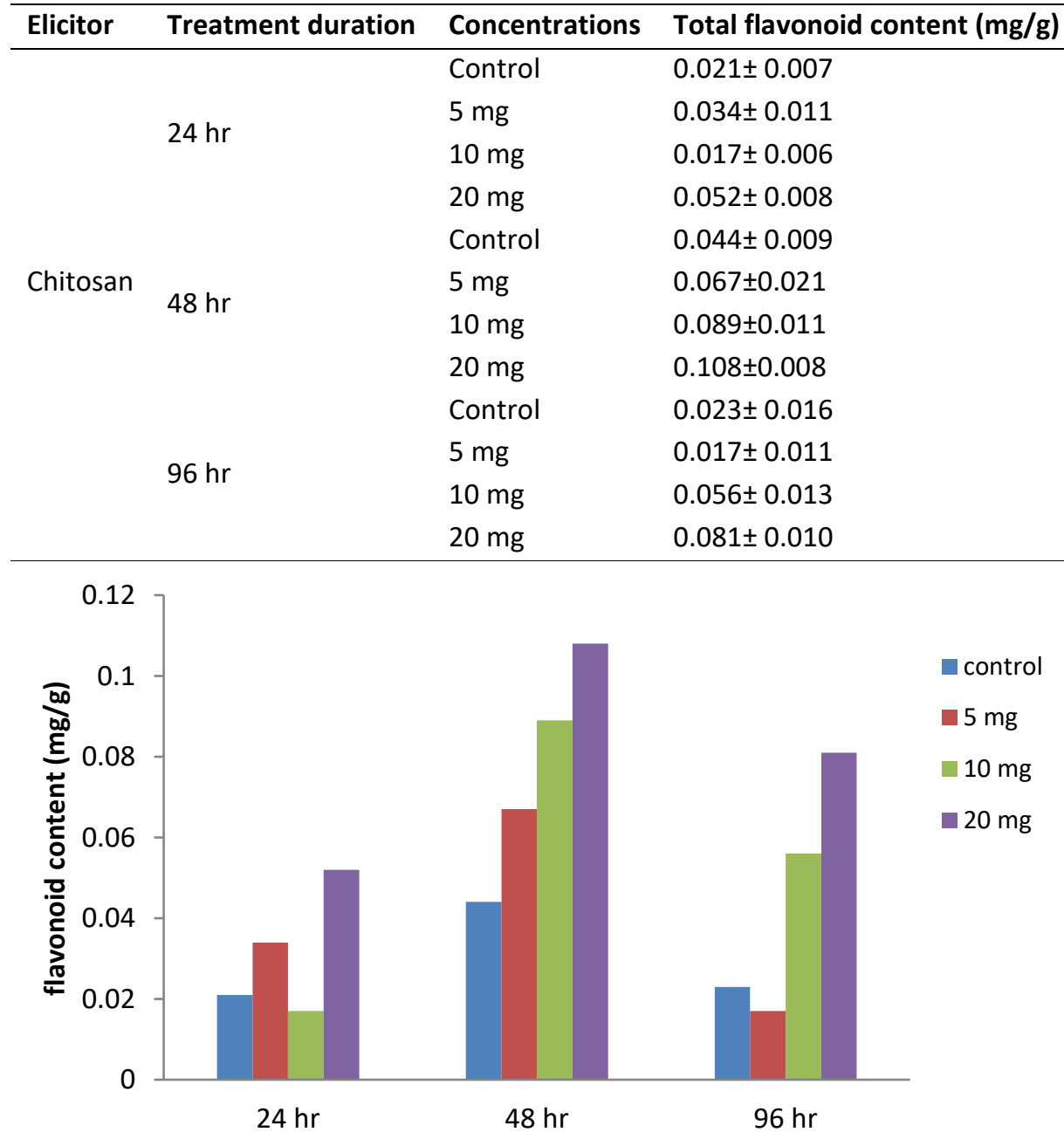

Fig.2: Effect of Chemical elicitor, Chitosan on total favonoid content

Chitosan has been used for enhancement in secondary metabolites production by many workers. The enhanced production of andrographolide and total flavonoid content was observed in cell suspension culture of Andrographis paniculata ${ }^{5,7}$.

The hairy root cultures of Trigonella foenum-graecum were treated with $0.5,1,2.5,5,10,20,30,40,50$ and $60 \mathrm{mg} / \mathrm{l}$ Chitosan concentrations to study the effect on diosgenin content ${ }^{24}$. The diosgenin content was significantly increased in all cases by the addition of Chitosan. Medium supplemented with $40 \mathrm{mg} / \mathrm{l}$ Chitosan showed the highest diosgenin content $(0.125 \%$ dry weight). This was three times the amount detected in the control roots $(0.040 \%$ dry weight) and five times the amount detected in the non-transformed roots. In Plumbago rosea, the elicitation of plumbagin production was 6.71-fold higher compared to control cells in $150 \mathrm{mg} / \mathrm{l}$ Chitosan concentration when incubated for $48 \mathrm{hr}{ }^{25} .20 \mathrm{mg} / \mathrm{l}$ of Chitosan was found most effective for paclitaxel production in callus of Taxus media. The paclitaxel content was $139 \mu \mathrm{g} / \mathrm{g}$ dry weight as compared to $89 \mu \mathrm{g} / \mathrm{g}$ dry weight in the control culture ${ }^{26}$. Chitosan increased the production of 
flavonoid glycosides by about 500\% after $24 \mathrm{hr}$ elicitation in Onosis arvensis ${ }^{27}$.

Elicitation by biological elicitor, Penicillium expansum: The fungal homogenate prepared from Penicillium expansum was used as biological elicitor. Cell suspension cultures were treated with $0.3 \%, 0.6 \%$ and $1.2 \%$ concentrations of fungal homogenate for 2,5 and 8 days treatment durations. The studied concentrations, $0.3 \%, \quad 0.6 \%$ and $1.2 \%$ Penicillium expansum for 2 days treatment duration showed $0.024 \pm$ $0.010,0.056 \pm 0.021$ and $0.053 \pm 0.011 \mathrm{mg} / \mathrm{g}$ total flavonoid content respectively whereas the quantity of flavonoid in control was $0.042 \pm 0.009 \mathrm{mg} / \mathrm{g}$. The flavonoid content in $0.3 \%$ concentration was reduced

Table 2: Total flavonoid content in Blumea lacera cell suspension cultures treated with biological elicitor, Penicillium expansum

\begin{tabular}{llll}
\hline Elicitor & Treatment duration & Concentrations & Total flavonoid content (mg/g) \\
\hline & \multirow{3}{*}{2 days } & Control & $0.042 \pm 0.009$ \\
& & $0.3 \%$ & $0.024 \pm 0.010$ \\
Penicillium expansum & $0.6 \%$ & $0.056 \pm 0.021$ \\
& \multirow{3}{*}{5 days } & $1.2 \%$ & $0.053 \pm 0.011$ \\
& & Control & $0.041 \pm 0.012$ \\
& & $0.3 \%$ & $0.057 \pm 0.015$ \\
& & $0.6 \%$ & $0.028 \pm 0.013$ \\
& & $1.2 \%$ & $0.019 \pm 0.008$ \\
& & Control & $0.029 \pm 0.006$ \\
& & $0.3 \%$ & $0.030 \pm 0.011$ \\
& & $0.6 \%$ & $0.028 \pm 0.003$ \\
\end{tabular}

Results obtained in all studied three treatment duration revealed variation, but these variations were not much encouraging. The positive variations were marginal in nature i.e. 1.3, 1.4 and 1.03-fold more content of compare to control whereas it was enhanced in $0.6 \%$ and $1.2 \%$. Higher content of flavonoid was recorded in $0.6 \%$ concentration. In case of 5 days treatment duration, $0.057 \pm 0.015 \mathrm{mg} / \mathrm{g}$ flavonoid content was observed in $0.3 \%$ concentration against control $(0.041 \pm$ $0.012 \mathrm{mg} / \mathrm{g}$ ). However, the flavonoid content in $0.6 \%$ concentration $(0.028 \pm 0.013 \mathrm{mg} / \mathrm{g})$ and $1.2 \%$ concentration $(0.019 \pm 0.008 \mathrm{mg} / \mathrm{g})$ was observed to be reduced than control. The studied concentrations for 8 days treatment duration showed $0.030 \pm 0.011,0.028 \pm$ 0.003 and $0.022 \pm 0.008 \mathrm{mg} / \mathrm{g}$ flavonoid content against $0.029 \pm 0.006 \mathrm{mg} / \mathrm{g}$ in control and it does not indicate sign of elicitation (Table-2; Fig. 3).

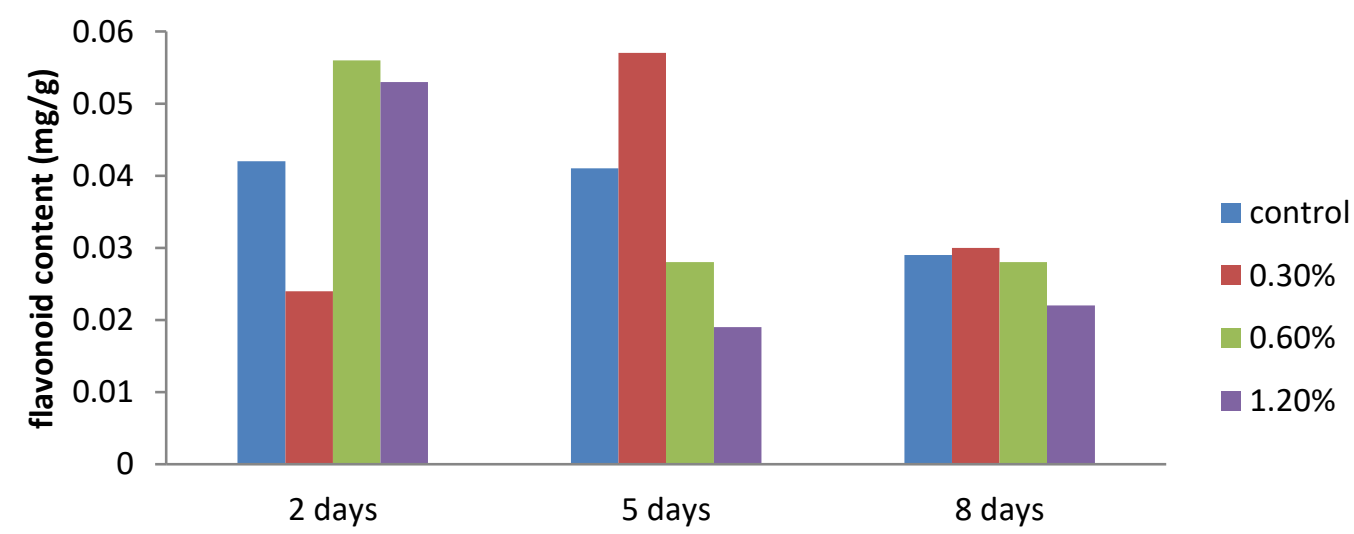

Fig.3: Effect of biological elicitor, Penicillium expansum on total flavonoid content 
Inspite the results obtained in the present work, it is to be noted here that the fungal elicitor Penicillium expansum is a preferred biological elicitor used by many workers in different plant systems. Addition of an elicitor derived from the fungus Penicillium expansum to a cell suspension culture of Sanguinaria canadensis induced the production of the benzo-phenanthridine alkaloids, sanguinarine and chelerythrine, in a dosedependent manner ${ }^{28}$. In Tagetes patula hairy root culture, $1.5 \%(\mathrm{v} / \mathrm{v})$ concentration of Penicillium expansum enhanced thiophene production upto $55 \%$ 29.

Though, elicitation enhances secondary metabolite synthesis in plants or plant cells in vitro but the exact mechanism of elicitation is not exactly understood. All elicitors do not follow the same sequence of events but varies with their origin, specificity, concentration, physiochemical environment, stage of their growth cycle, nutritional uptake etc. Various mechanisms in this regard have been hypothesized like messenger $\mathrm{Ca}^{2+}$, factors affecting cell membrane integrity, inhibition/ activation of intracellular pathways and changes in osmotic stress ${ }^{30-32}$, binding of the elicitor to a plasma membrane receptor for elicitation process ${ }^{33}$.

For successful elicitation of plant metabolites several important parameters need to be considered. These parameters are elicitor concentration and selectivity, treatment duration of elicitor, age of the culture, cell line, growth hormones, nutrient composition, and substantial enhancement of product accumulation ${ }^{34}$. Like dose concentration, treatment duration of elicitor also plays a crucial role in elicitation. Several studies has revealed that the prolonged exposure of cells to elicitors result in decrease in metabolic accumulation. For example, when cells of $C$. roseus exposed with elicitor extracts of $T$. viride, $A$. niger and $F$. moniliforme for $24 \mathrm{~h}, 48 \mathrm{~h}, 72 \mathrm{~h}$ and $96 \mathrm{~h}$. T. viride caused about 3-fold increase in ajmalicine production whereas, about twofold increase was observed with $A$. niger and $F$. moniliforme for $48 \mathrm{hr}$ in Catharanthus roseus ${ }^{35,36}$. However, further increasing exposure time resulted in decrease in ajmalicine content.

\section{CONCLUSION}

Findings of the present experiment indicate that Chitosan is efficient for elicitation of flavonoids in $B$. lacera. Chitosan dose of $20 \mathrm{mg}$ was the most favourable treatment dose among all studied treatment concentrations and durations that yields maximum elicitation of flavonoids (3.5 fold, $92 \mathrm{hr}$ treatment). Elicitation treatment of Penicillium expansum revealed most fluctuating results for flavonoid at lower and moderate treatment duration ( 2 and 5 days). Flavonoid content was more in $0.3 \%$ and less in $0.6 \%$ \& $1.2 \%$ concentration treatment compared to control. The 8 days treatment duration does not indicate any impact on elicitation of targeted compound.

\section{ACKNOWLEDEMENT}

The authors are thankful to the Director, The Institute of Science, Mumbai for providing the analytical facilities.

\section{REFERENCES}

1. Joy P.P., Thomas J., Mathew S. and Skaria B.P. (1998). Medicinal Plants, Kerala Agricultural University, Aromatic and Medicinal Plants Research Station, 3.

2. Do"rnenburg H. and Knorr D. (1995). Strategies for the improvement of secondary metabolite production in plant cell cultures. Enzym Microb Technol. 17: 674- 684.

3. Singh M. and Chaturvedi R. (2012). Evaluation of nutrient uptake and physical parameters on cell biomass growth and production of spilanthol in suspension cultures of Spilanthes acmella Murr. Bioprocess Biosyst Eng. 35: 943-951.

4. Ramawat K.G. and Merillon J.M. (1999). Biotechnology: secondary metabolites. New Delhi Oxford \& IBH: 199.

5. Vakil M.M.A. and Mendhulkar V.D. (2013). Salicylic acid and chitosan mediated abiotic stress in cell suspension culture of Andrographis paniculata (Burm.f.) Nees. for andrographolide synthesis. Int. J. of Pharm. Sc. and Research. 4 (9): 3453-3459.

6. Vakil M.M.A. and Mendhulkar V.D. (2013). Enhanced synthesis of andrographolide by

Aspergillus niger and Penicillium expansum elicitors in cell suspension culture of Andrographis paniculata (Burm. f.) Nees. Botanical studies. 54: 49.

7. Mendhulkar V.D. and Vakil M.M.A. (2013). Chitosan and Aspergillus niger mediated elicitation of total flavonoids in suspension culture of Andrographis paniculata (Burm.f.) Nees. Int J Pharm Bio Sci. B, 4(4): 731 - 740.

8. Mendhulkar V.D. and Vakil M.M.A. (2013). Elicitation of flavonoids by Salicylic acid and Penicillium expansum in Andrographis paniculata (Burm.f.) Nees. cell culture. Research in Biotech. 4(2): 01-09.

9. Tavares S., Vesentini D., Fernandes J.C., Ferreira R.B., Laureano O., Ricardo-da-silva J.M. and Amâncio S. (2013). Vitis vinifera secondary metabolism as affected by sulfate depletion: Diagnosis through phenylpropanoid pathway 
genes and metabolites. Plant Physiol. Biochem. 66: 118126.

10. Mendhulkar V.D., Moinuddin M.A. and Raut R.W. (2009). Saponin Estimation in Vigna radiata Cell Culture Treated with Cell Permeabilizing Agent, Triton X -100. Advances in Plant Sciences, India. 22 (I):1-5.

11. Mendhulkar V.D., Priyanka P. and Sandeep S. (2011). DMSO induced cell permeability in cell suspension culture of Bacopa monnieri Linn. Int. J of Pharm Sc and Res. 2(11): 3006-3009.

12. Radman R., Saez T., Bucke C. and Keshavarz T. (2003). Elicitation of plant and microbial systems. Biotechnol Appl Biochem. 37: 91-102.

13. Mulabagal V. and Tsay H. (2004). Plant cell cultures-An alternative and efficient source to produce biologically important secondary metabolites. Int. J. Applied Sci. Eng. 2: 29-48.

14. Namdeo A.G. (2007). Plant cell elicitation for production of secondary metabolites: A review. Pharmacognosy Rev. 1: 69-79.

15. Zhao J.L., Zhou L.G. and Wu J.Y. (2010). Effects of biotic and abiotic elicitors on cell growth and tanshinone accumulation in Salvia miltiorrhiza cell cultures. Appl Microbiol Biotechnol. 87: 137-144.

16. Gueven A. and Knorr D. (2011). Isoflavonoid production by soy plant callus suspension culture. J Food Eng. 103: 237-243.

17. Lin L. and Wu J. (2002). Enhancement of shikonin production in single- and two-phase suspension cultures of Lithospermum erythrorhizon cells using low-energy ultrasound. Biotechnol Bioeng. 5: 78-81.

18. Warrier P.K., Nambiar V.P.K. and Ramankutty C. (1996). Indian Medicinal Plants. Arya Vaidya Sala, Kottakkal. Orient Longman. 1: 135-138.

19. Quisumbing E. (1998). Medicinal Plants of the Philippines, 966-967.

20. Oudhia P., Joshi B.S. and Koshta V.K. (1998). Chhattisgarh ke kleshkarak kharptwaron se homoeopathic dava nirman kisambhavnayain (The possibilites of preparing homoeopathic drugs from obnoxious weeds of Chhattisgarh. Abstract: V National Science Conference, Bhartiya Krishi Anusandhan Samittee, JNKVV, Gwalior.

21. Patade P., Mendhulkar V.D. and Vakil M. (2016). Campesterol elicitation in Blumea lacera (Burm.f.) DC. cell culture using Salicylic acid and Aspergillus niger. Int J Green and Herbal Chem. B, 5(4): 308-318.

22. Males Z., Plazibat M., Vundac V.B. and Zuntar I. (2006). Qualitative and quantitative analysis of flavonoids of the strawberry tree - Arbutus unedo L. (Ericaceae). Acta Pharm. 56: 245-250.

23. Chang C.C., Yang M.H., Wen H.M. and Chern J.C. (2002). Estimation of total flavonoid content in propolis by two complementary colorimetric methods. Journal of Food and Drug Analysis. 10(3): 178-182.

24. Merkli A., Christen P. and Kapetanidis I. (1997). Production of diosgenine by hairy root cultures of Fenugreek (Trigonella foenum-graecum L.), Plant Cell Reports. 16: 632 - 636.

25. Komaraiah P., Amrutha R.N., Kishor P.B.K. and Ramakrishna S.V. (2002). Elicitor enhanced production of plumbagin in suspension cultures of Plumbago rosea $\mathrm{L}$. Enzyme and Microbial Technology. 31(5): 634-639.

26. Furmanowa M., Olędzka H., Sykłowska-Baranek K., Józefowicz J. and Gieracka S. (2000). Increased taxane accumulation in callus cultures of Taxus cuspidata and Taxus media by some elicitors and precursors. Biotechnology Letters. 22: 1449-1452.

27. Tumova L. and Backovska M. (1999). Chitosan and the flavonoid production. Herba Polonica. 45: 114-119.

28. Mahady G.B. and Beecher C.W.W. (1994). Elicitorstimulated benzophenanthridine alkaloid biosynthesis in bloodroot suspension cultures is mediated by calcium. Phytochemistry. 37: 415-419.

29. Buitelaar R.M., Cesário M.T. and Tramper J. (1992). Elicitation of thiophene production by hairy roots of Tagetes patula. Enzyme and Microbial Technology. 14: 27.

30. Cosio E.G., Frey T., Verduyn R., Boom J.V. and Ebel J. (1990). High affinity binding of a synthetic heptaglucoside and fungal glucan phytoalexin elicitors to soybean membranes. FEBS Lett. 271: 223-226.

31. Cheong J.J. and Hahn M.G. (1991). A specific, high-affinity binding site for the heptaglucoside elicitor exists in soybean membranes. Plant Cell. 3: 137-147.

32. Basse C.W., Fath A. and Boller T. (1993). High affinity binding of a glycopeptide elicitor to tomato cells and microsomal membranes and displacement by specific glycan suppressors. J. Biol. Chem. 268: 14724-14731.

33. Hanania U. and Avni A. (1997). High-affinity binding site for ethylene-inducing xylanase elicitor on Nicotiana tabacum membranes. Plant J. 12: 113-120.

34. Ganapathi G. and Kargi F. (1990). Recent advances in indole alkaloid production by Catharanthus roseus (Periwinkle). J. Exptl. Bot. 41: 259-267.

35. Namdeo G., Patil S. and Fulzele D.P. (2002). Influence of fungal elicitors on production of ajmalicine by cell cultures of Catharanthus roseus. Biotechnol Prog. 18: 159-162.

36. Namdeo G. (2004). Investigation on pilot scale bioreactor with reference to the synthesis of bioactive compounds from cell suspension cultures of Catharanthus roseus Linn. Ph.D. Thesis, Devi Ahilya Vishwavidyalaya, Indore, M.P. India. 
*Corresponding Author:

Mendhulkar Vijay D*

Email:profmendhulkar@gmail.com 